\title{
GROWTH AND PHYSIOLOGICAL RESPONSE OF COFFEE SEEDLINGS TREATED WITH FUNGICIDES
}

\author{
Viviane Maria Ruela ${ }^{1}$, Adriano Bortolotti da Silva ${ }^{2}$, André Delly Veiga $^{3}$, \\ Thiago Corrêa de Souza ${ }^{4}$, Daniele Maria Marques ${ }^{5}$, Carlos Emanuel de Melo Costa ${ }^{6}$, \\ Tiago Teruel Rezende ${ }^{7}$
}

(Received: February 04, 2019; accepted: March 22, 2019)

\begin{abstract}
Research has shown that, in addition to the fungicidal action already known, strobilurins have positive physiological effects on the yield of some crops. Boscalid has also shown positive effects on plants, applied together or associated with strobilurin. The objective in this study was to evaluate the effect of fungicide application on growth and physiological behavior of coffee seedlings. The experimental design was in randomized blocks, with five replicates. There were five treatments: T1-Control, T2-Boscalid, T3-Pyraclostrobin, T4- Boscalid+ Pyraclostrobin and T5- Azoxystrobin applied in coffee seedlings. The application was at the "orelha de onça" stage (two round-shaped leaves), repeated every 15 days, counting 5 applications in total. Were evaluated shoot length, root length, stem diameter, shoot and root fresh matter, shoot and root dry matter, leaf photosynthesis, stomatal conductance, transpiration, intercellular CO2 concentration, water use efficiency and carboxylation efficiency. The application of fungicides promotes greater vegetative growth of coffee seedlings due to increased $\mathrm{CO} 2$ assimilation rate, reduced transpiration rates and increased water use efficiency, associated to the increased levels of auxin and cytokinins in leaves.
\end{abstract}

Index terms: Strobilurin, pyraclostrobin, boscalid, gas exchange, Coffea arabica.

\section{CRESCIMENTO E RESPOSTAS FISIOLÓGICAS DE MUDAS DE CAFÉ TRATADAS COM FUNGICIDAS}

\begin{abstract}
RESUMO: Pesquisas vêm mostrando que além da ação fungicida já conhecida, as estrobilurinas possuem efeitos fisiológicos positivos sobre o rendimento de algumas culturas. A boscalida também tem mostrado efeito positivo, aplicada junto ou associado a estrobilurina. Objetivou-se avaliar o efeito da aplicação de fungicidas no crescimento e no comportamento fisiológico de mudas de cafeeiros. O delineamento experimental utilizado foi blocos casualisados, com cinco repetições. Foram cinco tratamentos: T1- Controle, T2- Boscalida, T3- Piraclostrobina, T4- Boscalida + Piraclostrobina, T5- Azoxistrobina, aplicados em mudas de café. A aplicação foi no estágio orelha de onça e repetidas a cada 15 dias, contabilizando cinco aplicações no total. As variáveis respostas analizadas foram: comprimento da parte aérea, comprimento do sistema radicular, diâmetro do caule, peso fresco da parte aérea e do sistema radicular, peso seco da parte aérea e do sistema radicular, taxa de fotossíntese foliar, condutância estomática, transpiração, concentração de $\mathrm{CO}_{2}$ intercelular, eficiência do uso da água e a eficiência de carboxilação. A aplicação de fungicidas promove maior crescimento vegetativo das mudas de café em função do aumento da taxa de assimilação de $\mathrm{CO}_{2}$, redução das taxas de transpiração e aumento da eficiência do uso da água, associado ao aumento dos teores de auxina e citocininas nas folhas.
\end{abstract}

Termos para indexação: Estrobilurinas, piraclostrobina, boscalida, trocas gasosas, Coffea arabica.

\section{INTRODUCTION}

Coffee tree is a perennial plant of tropical climate that belongs to the Rubiaceae family and to the Coffea genus, which includes several species of great economic interest, Coffea arabica and Coffea canephora, with $70 \%$ and $30 \%$, respectively, of the world production (ICO, 2018).

The obtention of coffee seedlings with high genetic and phytosanitary quality is an important step towards the successful implantation of the crop. For Matiello et al. (2010), a good coffee plant depends on a good seedling, since it is a perennial crop, and the plant will remain in the same place for many years.

In recent years, due to intensive soil use and large-scale coffee planting, fungal diseases have been observed, even during seedling production. Fungicides in general are the main tool to control the complex of fungal diseases that affect the coffee tree such as rust, phoma and cercosporiosis (PATROCINIO; OLIVEIRA, 2013). In addition to controlling the mentioned diseases, these products can still have positive physiological effects on plants (MACEDO, 2017).

\footnotetext{
1,2,6,7Universidade José do Rosário Vellano/UNIFENAS - Rod MG 179, Km 0 - Campus Universitário - 37.132-440 - Alfenas - MG viviruela@yahoo.com.br, adriano.silva@unifenas.br, carlosemanuel_10@hotmail.com, tiago.rezende@unifenas.br 4,5Universidade Federal de Alfenas/UNIFAL - Rua Gabriel Monteiro da Silva, 700 - 37.130-000 - Alfenas - MG - thiagonepre@hotmail.com, danimarques.bio@gmail.com

${ }^{3}$ Instituto Federal do Sul de Minas/IFSULDEMINAS - Rod Machado - Paraguaçu, Km 03 - 37.750-000 - Machado - MG andre.veiga@ifsuldeminas.edu.br
} 
Research has shown that boscalid is a fungicide of the class of anilides which, besides the fungicidal function, has a physiological effect on plants. This effect may be the result of liquid photosynthesis and nitrate reductase activity, associated with low ethylene production(SIRTOLI; RODRIGUES; GOTO, 2011). Once increasing liquid photosynthesis, it reduces plant respiration, consuming less carbon, which yields more plant energy (AMARO et al., 2018). Sirtoli, Rodrigues and Goto (2011), report the action of these products on the activity of antioxidant enzymes, and the activities of superoxide dismutase catalase and peroxidase were determined, confirming the anti-stress action in the treated plants.

Kozlowski et al. (2009) observed that bean plants treated with strobilurins in the absence of pathogenic fungi, had metabolic alterations that resulted in greater yield, besides being more vigorous. The application of this fungicide also presents positive results in relation to the increase in grain yield, as Rodrigues and Fioreze (2015) were based on the fact that strobilurins have an inhibitory effect on the activity of ACC synthase in maize plants, which is the key in ethylene (the hormone responsible for maize spike development) biosynthesis in the plant.

In this context, the objective in this study was to evaluate the effect of fungicide application on growth and physiological behavior of coffee seedlings.

\section{MATERIAL AND METHODS}

\section{Growth conditions and experimental design}

The experiment was carried out at the Federal Institute of Southern Minas Gerais, (IFSULDEMINAS), campus Machado, MachadoMG, with latitude $21^{\circ} 40^{\prime} 00^{\prime}$ "South, longitude $45^{\circ} 55^{\prime} 00^{\prime}$ "West and $873 \mathrm{~m}$ altitude. According to Koppen, the climate of the region is classified as CWA - rainy mesothermic, with dry winter and rainy summer.

The plant material consisted of 'Catuai' coffee plants (Coffea arabica L.), kept in a nursery covered with black photoconverter mesh, with $50 \%$ shading during the months of October to December 2015. The average temperature was $23.28^{\circ} \mathrm{C}$, relative humidity of $75 \%$ and cumulative precipitation of $517 \mathrm{~mm}$.

The design was in randomized blocks, consisting of 4 treatments with fungicides (boscalid, pyraclostrobin, boscalid + pyraclostrobin and azoxystrobin) and a control treatment, totaling 5 treatments (TABLE 1), with 5 replicates and 20 plants per plot, being considered as a useful plot, the six central seedlings.

The fungicides were applied with a $5 \mathrm{~L}$ costal sprayer, with a volume of $2 \mathrm{~L}$, and about 150 $\mathrm{mL}$ were applied per treatment. The applications started at the "orelha de onça" stage and were performed in the different treatments with a 15 day interval among them, totaling five applications throughout the trial. Irrigation and weed control were carried out according to the needs of the crop.

\section{Biometric and biomass measurements}

After 95 days of the first application of the treatments, 3 plants were evaluated per plot. Were evaluated shoot length (SL), root length (RL) stem diameter (stem Ø), number of leaves (NLEAVES), shoot (SFM) and root (RFM) fresh matter, shoot (SDM) and root (RDM) dry matter. Measurements were performed by means of caliper rule and a tape measure. In order to quantify the dry matter of leaves, stems and roots, the plant materials were washed to remove any particles and brought to a forced air oven at $60{ }^{\circ} \mathrm{C}$ until constant weight.

\section{Gas exchange}

Gas exchange parameters were measured using a portable photosynthesis system (IRGA, LI6400XT, Li-Color, Lincoln, Nebraska, USA) at the end of the experiment at 90 days. Measurements were performed in the morning from 9.00 a.m. to $11.00 \mathrm{a} . \mathrm{m}$. in fully expanded leaves. Three expanded leaves were selected per plot, and the second pair of leaves was evaluated, counting from the apical region. The evaluated parameters were leaf photosynthesis (A), stomatal conductance $\left(\mathrm{g}_{\mathrm{s}}\right)$, transpiration (E), intercellular $\mathrm{CO}_{2}$ concentration $\left(\mathrm{C}_{\mathrm{i}}\right)$, water use efficiency $(\mathrm{A} / \mathrm{E})$ and carboxylation efficiency $\left(\mathrm{A} / \mathrm{C}_{\mathrm{i}}\right)$. Measurements were performed on a $6 \mathrm{~cm}^{2}$ leaf area and the chamber airflow was at a $\mathrm{CO}_{2}$ concentration of $380 \mathrm{mmol} \mathrm{mol}{ }^{-1}$. The air was collected from outside the nursery and transported to one buffer gallon and then pumped into the chamber, in order to standardize the entry of $\mathrm{CO}_{2}$ into the equipment (LI-COR, 2019).. An $800 \mu \mathrm{mol} \mathrm{m}{ }^{-2} \mathrm{~s}^{-1}$ photon flux density (PPFD) was used with a red-blue LED light source and the chamber temperature was $28^{\circ} \mathrm{C}$. 
TABLE 1 - Fungicides used in the different treatments.

\begin{tabular}{cc}
\hline Treatments & $\begin{array}{c}\text { Active Ingredient Dose } \\
\left(\mathrm{g} \text { or mL } 100 \mathrm{~L}^{-1}\right)\end{array}$ \\
\hline Control & - \\
Boscalid* & 37.5 \\
Pyraclostrobin** & 37.5 \\
Boscalid + Pyraclostrobin & $37.5+37.5$ \\
Azoxystrobin*** & 25.0 \\
\hline Concentration of the active ingredient: $* 500 \mathrm{~g} \mathrm{~kg}^{-1}, * * 250 \mathrm{~g} \mathrm{~L}^{-1}, * * * 500 \mathrm{~g} \mathrm{~kg}^{-1}$ &
\end{tabular}

\section{Phytohormones}

For the quantification of phytohormone content (3-indoleacetic acid, kinetins, abscisic acid), healthy leaves were selected per plot (20 $\mathrm{mg}$ ), resulting in $100 \mathrm{mg}$ of fresh plant material for each of the five treatments. The samples were placed in liquid nitrogen $\left(-80^{\circ} \mathrm{C}\right)$ immediately after collection and kept during the transport from the nursery to the laboratory (Botucatu, SP).

The samples were removed from liquid nitrogen and added to $10 \mathrm{~mL}$ of extraction solution (acetonitrile: Mili-Q water 1:1). After addition, they were briefly vortexed and shaken for 30 minutes in a shaker and centrifuged at $16,000 \mathrm{~g}$ and $4{ }^{\circ} \mathrm{C}$ for 5 minutes. The supernatant was transferred to a new microcentrifuge tube (1.5 $\mathrm{mL}$ ) and dried in VCA speed. After drying, $100 \mu \mathrm{L}$ of methyl alcohol $(\mathrm{MeOH})$ were added to each of the samples, centrifuged again at 16,000g and 4 ${ }^{\circ} \mathrm{C}$ for 10 minutes. The supernatant was analyzed by HPLC/MS, as described by Trapp et al. (2014).

\section{Data analysis}

Biometric and mass accumulation data were submitted to analysis of variance (ANOVA) using the Sisvar statistical software (FERREIRA, 2011) and the means were grouped by the Skott-Knott test. For the other variables (Phytohormones), descriptive statistics was used, and the means and the standard error (SE) were calculated.

\section{RESULTS AND DISCUSSION}

\section{Plant growth}

The application of fungicides of anilide and strobilurin groups influenced shoot (SL) and root (RL) length, stem diameter (STEM Ø), number of leaves (NLEAVES), shoot (SFM) and root (RFM) fresh matter, as well as shoot dry matter (SDM). On the other hand, root dry matter (RDM) was not influenced by fungicide application, with a mean dry matter of $0.74 \mathrm{~g}$ (TABLE 2).

The treatments Pyraclostrobin+Boscalid and Pyraclostrobin yielded the highest shoot lengths, reaching 16.09 and $15.17 \mathrm{~cm}$, respectively (TABLE 2) and were 24 and $17 \%$ higher in relation to the control treatment. In seedlings in which the Pyraclostrobin fungicide or the combination Boscalid+Pyraclostrobin were applied, a higher RL was observed. The other treatments with fungicides were similar to the control treatment (TABLE 2).

The stem diameter of coffee seedlings was influenced by the application of fungicides, and the seedlings that received the Boscalid+Pyraclostrobin treatment had the largest diameter $(3.92 \mathrm{~cm}), 43 \%$ higher than the seedlings that did not receive any fungicide (TABLE 2).

Similarly, to that observed for SL, the application of Boscalid+Pyraclostrobin or Pyraclostrobin yielded a larger number of leaves (NLEAVES), averaging 12.73 and 11.27 leaves per plant, respectively, (TABLE 2). This result is probably due to the fact that plants with higher SL tend to have a greater number of internodes and, consequently, more leaves.

In relation to the variables SFM and RFM, better results were observed in plants treated with Boscalid+Pyraclostrobin, reaching 6.70 and $2.50 \mathrm{~g}$, respectively (TABLE 2). The same behavior was observed for SDM, where the use of Boscalid+Pyraclostrobin resulted in greater mass accumulation $(1.81 \mathrm{~g})$, when compared to the other treatments (TABLE 2). Dry matter represents the actual plant growth, by removing water from the tissues, resulting in the mass accumulated as a function of photosynthesis results. In general, the use of Boscalid+Pyraclostrobin led to the greatest plant growth for all analyzed variables, except RL (TABLE 2). 
TABLE 2 - Shoot length (SL), root length (RL), stem diameter (stem Ø), number of leaves (N LEAVES), shoot fresh matter (SFM), root fresh matter (RFM), shoot dry matter (SDM) and root dry matter (RDM), as a function of the different treatments.

\begin{tabular}{ccccc}
\hline Treatment & SL $(\mathrm{cm})$ & RL $(\mathrm{cm})$ & STEM Ø $(\mathrm{mm})$ & N LEAVES \\
\hline Boscalid & $14.22 \mathrm{~B}$ & $10.34 \mathrm{~B}$ & $3.01 \mathrm{C}$ & $8.33 \mathrm{~B}$ \\
Pyraclostrobin & $15.17 \mathrm{~A}$ & $13.15 \mathrm{~A}$ & $3.31 \mathrm{~B}$ & $11.27 \mathrm{~A}$ \\
Azoxystrobin & $14.33 \mathrm{~B}$ & $10.93 \mathrm{~B}$ & $3.32 \mathrm{~B}$ & $7.33 \mathrm{~B}$ \\
Boscalid + Pyraclostrobin & $16.09 \mathrm{~A}$ & $13.63 \mathrm{~A}$ & $3.92 \mathrm{~A}$ & $12.73 \mathrm{~A}$ \\
Control & $12.93 \mathrm{~B}$ & $10.71 \mathrm{~B}$ & $2.74 \mathrm{C}$ & $6.87 \mathrm{~B}$ \\
\hline Treatment & SFM $(\mathrm{g})$ & RFM $(\mathrm{g})$ & $\mathrm{SDM}(\mathrm{g})$ & $\mathrm{RDM}(\mathrm{g})$ \\
\hline Boscalid & $4.32 \mathrm{~B}$ & $1.21 \mathrm{C}$ & $1.34 \mathrm{~B}$ & $0.76 \mathrm{~A}$ \\
Pyraclostrobin & $5.06 \mathrm{~B}$ & $1.87 \mathrm{~B}$ & $1.36 \mathrm{~B}$ & $0.78 \mathrm{~A}$ \\
Azoxystrobin & $4.17 \mathrm{~B}$ & $1.06 \mathrm{C}$ & $1.30 \mathrm{~B}$ & $0.65 \mathrm{~A}$ \\
Boscalid + Pyraclostrobin & $6.70 \mathrm{~A}$ & $2.50 \mathrm{~A}$ & $1.81 \mathrm{~A}$ & $0.85 \mathrm{~A}$ \\
Control & $2.95 \mathrm{C}$ & $0.99 \mathrm{C}$ & $0.97 \mathrm{C}$ & $0.66 \mathrm{~A}$ \\
\hline Means followed by the same vertical capitalletter belong to the same group by the Scott-Knott test at 5\% probability.
\end{tabular}

The accumulation of dry phytomass in the stem and other plant structures is an important characteristic for several crops, as part of this phytomass can be remobilized, especially during stress periods (SOARES et al., 2011). In coffee seedlings, this phytomass accumulation is mainly necessary for plant support, as well as for the formation of productive branches.

Regarding the number of leaves, the influence of Pyraclostrobin is clear, since the treated plants behaved differently from the control. The seedlings showed larger SL and N LEAVES (TABLE 2), leading to a greater photosynthetic capacity, contributing to a better initial seedling development. This growth can be attributed to the physiological changes caused by the use of this fungicide, which favors the initial growth and development of several crops (GROSSMANN; RETZLAFF, 1997; BRYSON; LEANDRO; JONES, 2000). However, this performance did not result in higher dry matter accumulation (TABLE 2).

The molecule pyraclostrobin has been reported by several authors as inducing physiological effects and promoting plant growth. Cunha et al. (2015) observed that the seed treatment with pyraclostrobin increased plant height, fresh and dry matter, besides shoot and root in the soybean crop. In wheat, phenometric and biochemical variables were positively affected, as there was greater leaf retention and grain yield with the use of pyraclostrobin (BRYSON; LEANDRO; JONES, 2000).
The use of boscalid alone, or in combination with pyraclostrobin, showed beneficial physiological effects that led to the growth of different crops such as soybean (RODRIGUES 2009), cucumber (AMARO et al., 2018; AMARO, 2009), melon (MACEDO, 2017) and tomato (RAMOS, 2009). In addition, this molecule can yield better photosynthetic rates (MACEDO, 2017), which may have positively contributed to the growth of coffee seedlings.

In this study, there was probably a synergistic effect in which the combination of pyraclostrobin (Pyraclostrobin) with boscalid (Boscalid) showed, in general, plants with higher growth, when compared to the use of these molecules alone (TABLE 2), which was also reported by Amaro et al. (2018) for plant growth in cucumber crop.

Azoxystrobin had good results for RL and SDM, when compared to the control treatment (TABLE 2). However, for the other variables, the use of Azoxystrobin showed the lowest performance in relation to the other fungicides (TABLE 2). In the present study it was observed visually low occurrence of disease (Cercospora coffeicola) only found in plants of the control treatment.

\section{Gas exchange}

Better results for the variable $\mathrm{CO}_{2}$ assimilation rate (A) were observed with the use of the combination Pyraclostrobin+Boscalid (FIGURE 1A). These results are in agreement 
with those evaluated by Amaro et al. (2009), in the cucumber crop, and by Ramos (2013), in the tomato crop. With the use of Boscalid in the cucumber crop, Sirtoli; Rodrigues; Goto (2011) verified an increase in the $\mathrm{CO}_{2}$ assimilation rate. Similarly, Fagan and Casaroli (2007) also observed an increase in $\mathrm{CO}_{2}$ assimilation in the soybean crop, but with the use of pyraclostrobin.

The use of different fungicide treatments led to a decrease in stomatal conductance $\left(\mathrm{g}_{\mathrm{s}}\right)$, as well as in internal carbon $\left(\mathrm{c}_{\mathrm{f}}\right)$ and transpiration rates (E) (FIGURE 1BCD). Nasson et al. (2007) worked with the application of strobilurins, such as kresoxim-methyl, pyraclostrobin, azoxystrobin, trifloxystrobin and picoxystrobin, and verified a decrease in transpiration rate and stomatal conductance in wheat, barley and soybean.

Plants treated with azoxystrobin showed the second lowest photosynthesis (A), transpiration $(\mathrm{E})$, carboxylation efficiency $(\mathrm{Ci} / \mathrm{Ca})$ and stomatal conductance $\left(\mathrm{g}_{\mathrm{s}}\right)$ (FIGURE $1 \mathrm{~A}, \mathrm{~B}, \mathrm{D}$ and $\mathrm{F}$ ), as observed by Amaro et al. (2018) in cucumber plants.

Ramos (2013) verified that tomato plants treated with pyraclostrobin had lowercarboxylation efficiency, photosynthesis, transpiration and stomatal conductance and greater efficiency of water use, which, according to Ramos (2013), may be due to the control of transpiration, a fact that was observed in this study. On the other hand, the mixture of Boscalid with Pyraclostrobin had a lower water use efficiency, with a high $\mathrm{CO}_{2}$ assimilation, in the same study, with tomato crop, where transpiration and stomatal conductance were low (FIGURE 1A).

The plants treated with pyraclostrobin had the lowest transpiration rate, caused by the low stomatal conductance, which led to a high efficiency water use, and showed a good carboxylation efficiency, which may have positively contributed to SL and NLEAVES, but this did not result in greater mass accumulation (SDM), since the mixture pyraclostrobin+boscalid was the best treatment in the phenometric variables (TABLE 2).

Plants treated with the mixture of fungicides boscalid + pyraclostrobin showed a greater photosynthesis (A), associated to low transpiration rates $(\mathrm{E})$ and stomatal conductance $\left(\mathrm{g}_{\mathrm{s}}\right)$ (FIGURE 1A, B and D), which resulted in good capacity to assimilate $\mathrm{CO}_{2}$ with minimum water loss, thus having the best water use efficiency (A/E) (FIGURE 1E).

Freitas Filho (2014) verified that, for water use efficiency (E/A), the treatment with boscalid + pyraclostrobin behaved more significantly in relation to the control for sweet pepper.
The $\mathrm{C}_{\mathrm{i}} \mathrm{C}_{\mathrm{a}}$ ratio demonstrates the internal $\mathrm{CO}_{2}$ concentration (intercellular spaces), compared to the external $\mathrm{CO}_{2}$ concentration. Considering that the external concentration of $\mathrm{CO}_{2}\left(\mathrm{C}_{\mathrm{a}}\right)$ was kept, the increase in the $\mathrm{Ci} / \mathrm{Ca}$ ratio is only due to the variation in internal concentration $\left(C_{i}\right)$. In the case of control seedlings, if $\mathrm{C}_{\mathrm{i}}$ is increasing, it means that $\mathrm{CO}_{2}$ is arriving in the mesophyll cells, but it is not being fixed in the carboxilative phase, which may have contributed to the lower photosynthesis (A) of these plants, when compared to the plants submitted to the treatment boscalid+pyraclostrobin (FIGURE 1A and F).

Regarding the plants treated with Boscalid, Pyraclostrobin and Azoxystrobin, despite the decrease in the $\mathrm{C}_{\mathrm{i}} / \mathrm{C}_{\mathrm{a}}$ ratio, this behavior did not increase the photosynthesis (A) in relation to the control plants, as well as those submitted to the best treatment (FIGURE 1A and F). This fact may have occurred due to the stomatal closure observed in plants submitted to these treatments (FIGURE 1B), which may have reduced $\mathrm{CO}_{2}$ input into the leaf mesophyll and/or probably due to a low efficiency of the reactions in the carboxylation phase, reducing $\mathrm{CO}_{2}$ fixation (A). However, this behavior observed in relation to gas exchange did not negatively affect the development of plants treated with these fungicides, which were higher than the control plants for the variables SFM, SDM and STEM Ø (TABLE 2).

Nason et al. (2007) reported that the application of strobilurins, such as kresoximmethyl, pyraclostrobin, azoxystrobin, trifloxystrobin and picoxystrobin, reduced the $\mathrm{CO}_{2}$ net assimilation rate, transpiration rate and stomatal conductance in wheat, barley and soybean. This is probably due to the reduction in ATP production caused by the blockage of electron transport in the cytochrome bc1 complex, which may have impaired the normal metabolism in guard cells, reducing turgor and, consequently, stomatal opening, since the osmotic potential of guard cells is limited by the production of ATP. The $\mathrm{Fv} / \mathrm{Fm}$ ratio was also reduced, indicating that strobilurins directly inhibited photosynthesis, perhaps independently of what might have occurred in the stomata (NASON et al., 2007). This behavior verified by Nason et al. (2007), explains what probably occurred in coffee plants submitted to the isolated application of fungicides. However, the plants that received Boscalid+Pyraclostrobin had the best $\mathrm{CO}$ assimilation rate (FIGURE 1A), even with a reduction in transpiration rate and stomatal conductance (FIGURE 1B and D). The combination of fungicides probably worked to reduce the inhibition effects of $\mathrm{CO}_{2}$ fixation by the photosynthetic apparatus of coffee plants. 

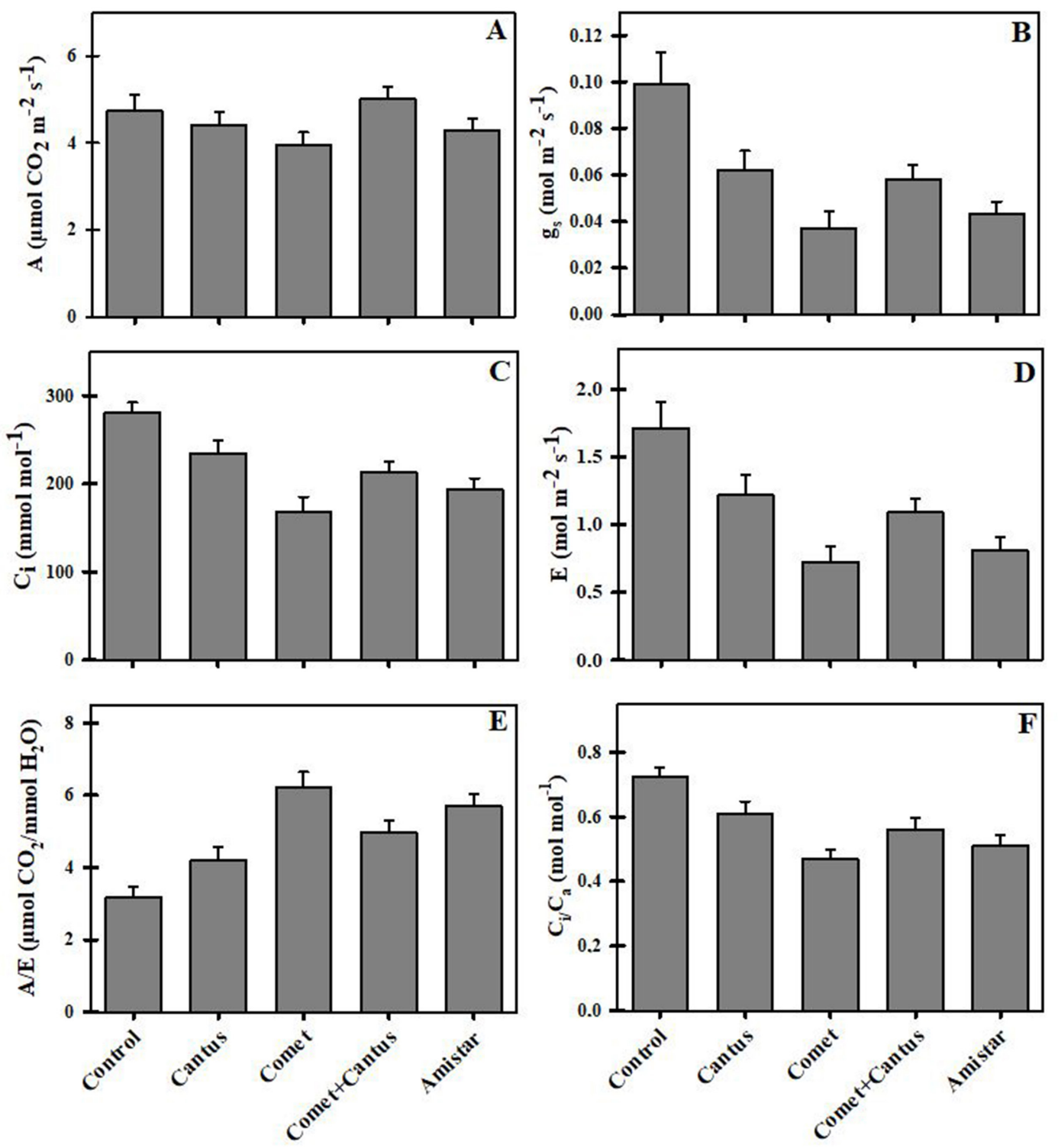

FIGURE 1 - Photosynthesis $\left(\mathrm{A}, \mu \mathrm{mol} \mathrm{CO} \mathrm{Cm}^{-2} \mathrm{~s}^{-1}\right)$, stomatal conductance $\left(\mathrm{g}_{\mathrm{s}}, \mathrm{mol} \mathrm{m}^{-2} \mathrm{~s}^{-1}\right)$, transpiration (E, mol water vapor $\mathrm{m}^{-2} \mathrm{~s}^{-1}$ ), water use efficiency $\left(\mathrm{WUE}-\mathrm{A} / \mathrm{E}, \mu \mathrm{molCO}_{2} / \mathrm{mmol} \mathrm{H}_{2} \mathrm{O}\right)$ and carboxylation efficiency $\left(\mathrm{C}_{\mathrm{i}} / \mathrm{C}_{\mathrm{a}}\right.$, mol mol-1) in 'Catuai' coffee seedling leaves grown in a nursery and treated with different fungicides, 90 days after the first application. Treatments: Boscalid (Bosca); Pyraclostrobin (Pyraclos) e Azoxystrobin (Azoxy).

\section{Phytohormones}

The use of the different fungicides alone (Boscalid, Pyraclostrobin and Azoxystrobin) or in combination (Pyraclostrobin+Boscalid) led to changes in the hormone concentrations of plants in relation to plants that did not receive fungicides (FIGURE 2).

The application of Boscalid increased auxins, cytokinins and abscisic acid (FIGURE 2A, B and C). The application of pyraclostrobin
(Pyraclostrobin) yielded a positive increase in cytokinin concentrations and abscisic acid reduction (FIGURE $2 \mathrm{~B}$ and $\mathrm{C}$ ). The action of azoxystrobin (Azoxystrobin) resulted in increased cytokinin concentrations and reduction in auxin and abscisic acid (FIGURE 2A, B abd C).

The use of the mixture (Boscalid+Pyraclostrobin) in the plants, led to increase in auxin and cytokinin concentrations, when compared to the control plants (FIGURE 2 $\mathrm{A}, \mathrm{B}$ and $\mathrm{C})$. 


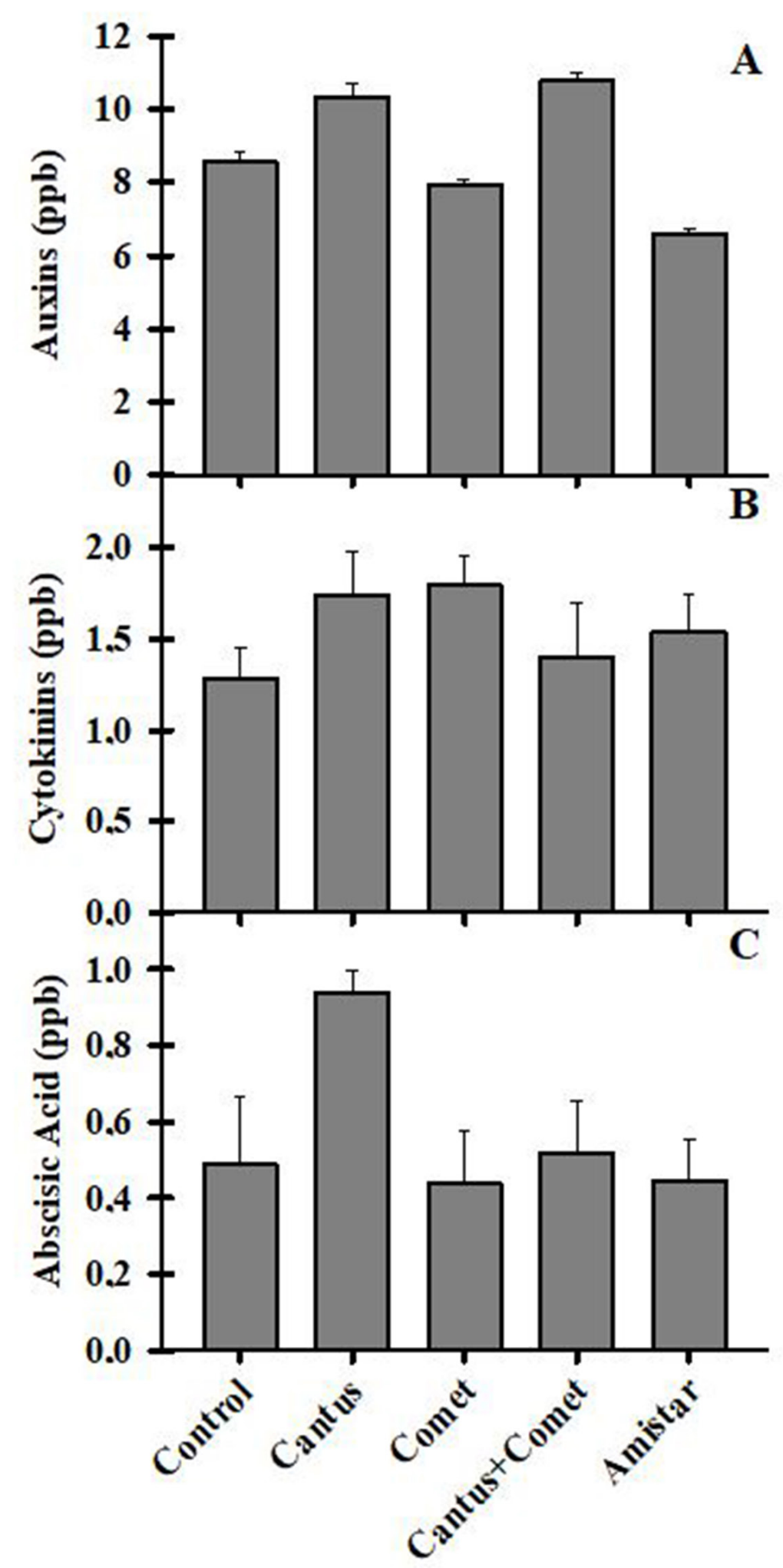

FIGURE 2 - Levels of auxins (A), cytokinins (B) and abscisic acid (C), in 'Catuaí' coffee seedling leaves grown in a nursery and treated with different fungicides, 90 days after the first application. Treatments: Boscalid (Bosca); Pyraclostrobin (Pyraclos) e Azoxystrobin (Azoxy). 
Phytohormones are substances that, even at low concentrations, lead to physiological changes in plants. Auxins are related to plant growth at height, rooting of cuttings, fruit growth and apical dormancy (TAIZ; ZEIGER, 2011); on the other hand, cytokinins cause cell division, avoiding leaf senescence, causing the so-called "green" or physiological effect in plants. Abscisic acid is related to plant growth inhibition, stomatal closure, seed and plant dormancy, and is produced in response to possible environmental stresses.

In this context, the combination of boscalid+pyraclostrobin, led to plant growth (TABLE 2), better photosynthesis rates (FIGURE 1A) and water use efficiency (A/E) (FIGURE 2A and $\mathrm{E}$ ), due to the beneficial effects of high auxin/ cytokinin concentrations (FIGURE 2A andB), resulting in higher plant growth (FIGURE $2 \mathrm{~A}, \mathrm{~B}$ and $\mathrm{C}$ ).

The use of strobilurins in wheat crops led to increased ABA concentrations, reduced transpiration and stomatal closure (CASTRO; ZANCAN; JULIATTI, 2016). However, in this study, there was no trend in increasing $\mathrm{ABA}$ concentration (FIGURE 2C) with the use of these fungicides. The increase in ABA concentration was only observed with the use of Boscalid (FIGURE 2C).

Strobilurin (Pyraclostrobin and Azoxystrobin) influences the hormonal status of the plant, not by increasing auxin concentrations, but with auxin-like bioregulatory activities, stimulating rooting in tobacco, seed germination in wheat, inhibiting the formation of ethylene (GROSSMANNetal.,1999).Inaddition, strobilurin promotes an increase in cytokinin concentrations, slowing the degradation of chlorophyll, causing the "green effect", and is still related to the increase in the synthesis of proteins and carbohydrates (GROSSMANN et al., 1999; YPEMA; GOLD, 1999; GROSSMANN; RETZLAFF, 1997; DAVIES, 2010). A similar behavior was observed in this study, with plants submitted to strobilurin applications (Pyraclostrobin and Azoxystrobin), where a higher concentration of cytokinins was observed, due to an increase in auxin levels (FIGURE 2AB). However, the best physiological effect of strobilurins was with the application of pyraclostrobin (Pyraclostrobin) on plant growth, mainly for SL and N LEAVES (TABLE 2).

The application of strobilurins and boscalid in the different crops still show contradictory results in relation to physiological effects.
Research should be improved, taking into account the interaction species, time of application and concentration of the product, in order to optimize the beneficial effects of these molecules in agriculture. However, the use of these substances is positive in plant growth by the use of Boscalid or Pyraclostrobin alone, but mainly the combination of these fungicides applied in coffee seedlings.

\section{CONCLUSIONS}

The tested fungicides (boscalid, pyraclostrobin and azoxystrobin) have positive physiological effects on coffee seedlings, mainly in relation to the increase in stomatal conductance and transpiration reduction, as well as a greater dry matter accumulation in the shoot in relation to the control plants.

\section{ACKNOWLEDGEMENTS}

The authors would like to thank Fundação de Amparo à Pesquisa de Minas Gerais (FAPEMIG), for the financial support for conducting this research.

\section{REFERENCES}

AMARO, A. C. E. et al. Effects of the fungicides azoxystrobin, pyraclostrobin and boscalid on the physiology of Japanese cucumber. Scientia Horticulturae, Amsterdam, v. 228, p. 66-75, 2018.

AMARO, A.C.E.; MACEDO, A.C. et al. Influência de alguns fungicidas nas trocas gasosas e produção de plantas de pepino japonês enxertadas e não enxertadas, em condições de ambiente protegido. Horticultura Brasileira, Botucatu, v. 27, n. 2, p. S1964-S1970, ago. 2009

BRYSON, R. J.; LEANDRO, L.; JONES, D. R. The physiological effects of kresoxim-methyl on wheat leaf greenness and the implication for crop yield. In: BRIGHTON CROP PROTECTION CONFERENCEPESTS AND DISEASES, 2000, Farnham. Proceedings... Farnham: British Crop Protection Council, 2000. p. 739-747.

CASTRO, R. L. A.; ZANCAN, N. L. B.; JULIATTI, F. C. Alterações fisiológicas causadas por fungicidas em soja infectada naturalmente por oídio. In: 49 Congresso Brasileiro de Fitopatologia, 2016, Maceió. Anais... Brasília: SBF, 2016. v. 1. p. 1-1.

CUNHA, R. P. et al. Diferentes tratamentos de sementes sobre o desenvolvimento de plantas de soja. Ciência Rural, Santa Maria, v. 45, n. 10, p. 1761-1767, out. 2015. 
DAVIES, P. J. Plant Hormones: Biosynthesis, Signal Transduction. Action! 3. ed. Heidelberg: Springer Netherlands, 2010, 845p.

FAGAN, E. B; CASAROLI, D. Análise temporal de variáveis fisiológicas da cultura da soja após a aplicação de estrobirulina. Cultura Agronômica, Ilha Solteira, v. 23, n. 2, p. 135-144, 2014.

FERREIRA, D. F. Sisvar: A computer statistical analysis system. Ciência e Agrotecnologia, Lavras, v. 35, n. 6, p. 1039-1042, nov./dez. 2011.

FREITAS FILHO, A.M. Fungicidas de efeito fisiológico no desenvolvimento de plantas de pimentão enxertadas e não enxertadas sob cultivo protegido. 2014. 54 p. Dissertação (Mestrado em Agronomia) - Universidade Estadual Paulista "Júlio de Mesquita Filho". Faculdade de Ciências Agronômicas, Botucatu, 2014.

GROSSMANN, K.; KWIATKOWSKI, J.; CARPAR, G. Regulation of phytohormone levels, leaf senescence and transpiration by the strobilurin kresoxim-methyl in wheat (Triticum aestivum). Journal of Plant Physiology, Stuttgard, v. 154, p. 805-808, 1999.

GROSSMANN, K; RETZLAFF, G. Bioregulatory effects of the fungicidal strobilurin kresoxim methyl in wheat (Triticum aestivum L). Pesticide Science, Oxford, v. 50, p. 11-20, 1997.

International Coffee Organization, ICO. Total production by all exporting countries. Available at: $<$ http://www.ico.org/prices/po-production.pdf $>$. Accessed on Set 30, 2018.

KOZLOWSKI, L.A. et al. Efeito fisiológico de estrobilurina F 500® no crescimento e rendimento do feijoeiro. Revista Acadêmica: Ciências Agrárias e Ambientais. Curitiba, v. 7, n. 1, p. 41-54, 2009.

LI-COR. Comparing a $\mathrm{CO}_{2}$ controller with buffer volumes in respiration measurements. licor.com. 2019. Disponível em: <https:/www.licor.com/env/support/ LI-6400/topics/buffer-volume.html?fbclid=IwAR1Mg TOjh8jBVL2kvdb-TJAg5f2DgRetUSC2DnT2YsjpFd sWn8Df64MUvVo> Acesso: 19 mar. 2019.

MACEDO, A.C et al. Strobilurin and boscalid in the quality of net melon fruits. Semina: Ciências Agrárias, Londrina, v. 38, n. 2, p. 543-550, mar./abr. 2017.
MATIELlO, J.B. et al. Cultura do café no Brasil: novo manual de recomendações. Rio de Janeiro: MAPA/PROCAFÉ, 2010. 548p.

NASON, M. A.; FARRAR, J.; BARLETT, D. Strobilurin fungicides induce changes in photosynthetic gas exchange that do not improve water use efficiency of plants grown under conditions of water stress. Pest Management Science, Sussex, v. 63, n. 12, p. 11911200, 2007.

PATROCÍNIO F., OLIVEIRA E. Desafio do manejo no controle das doenças do café. Visão Agrícola, Piracaba, n. 12, p. 51-54, jan./jul. 2013.

RAMOS, A.R.P. et al. Qualidade de frutos de tomate 'giuliana' tratados com produtos de efeitos fisiológicos. Semina: Ciências Agrárias, Londrina, v. 34, n. 6, p. 3543-3552, 2013.

RODRIGUES, M. A. T. Avaliação do efeito fisiológico do uso de fungicidas na cultura de soja. 2009. 197 p. Tese (Doutorado em Fitotecnia) - Escola Superior de Agricultura "Luiz de Queirós”, Universidade de São Paulo, Piracicaba, 2009.

RODRIGUES, J. D.; FIOREZA, S. L. Reguladores são, para muitos cultivos, indispensáveis ao alcance de bons níveis. Visão Agrícola, Piracicaba, n. 13, p. 35$39,2015$.

SIRTOLI, L.F.; RODRIGUES, J.D.; GOTO, R. Efeito fisiológico do fungicida boscalida na atividade do nitrato redutase e nas características fitotécnias de pepineiro japonês enxertado e não enxertado. Scientia Agraria Paranaensis, Marechal Cândido Rondon, v. 10, n. 3, p. 58-69, 2011.

SOARES, L.H. et al. Aplicação de diferentes estrobilurinas na cultura da soja. Revista da Faculdade de Zootecnia, Veterinária e Agronomia, Uruguaiana, v. 18 , n. 1 , p. $78-97,2011$

TAIZ, L.; ZEIGER, E. Fisiologia vegetal. 5. ed. Porto Alegre: Artmed, 2011. 690 p.

TRAPP, M. O. et al. Validated method for phytohormone quantification in plants. Frontiers in Plant Science. Lausanne Switzerland, v. 5. n. 417, p. 1-11, ago. 2014.

YPEMA, H. L.; GOLD, R. E. Kresoxym-methyl modification of a naturally occurring compound to produce a new fungicide. Plant Disease, Saint Paul, v. 83, n. 1, p. 4-19, 1999. 